\title{
AN ANALYSIS PHRASE LEUEL TRANSLATION TECHNIQUES APPLIED ON HEROES BACKGROUND IN MOBILE LEGENDS BANG-BANG GAME
}

\author{
Kristanya Debora Ratulangi \\ kristanya.2014ude023@civitas.ukrida.ac.id \\ Faculty of Humanities and Social Sciences,Universitas Kristen Krida Wacana, Jakarta
}

\begin{abstract}
This study investigated the translation techniques applied from Mobile Legend: Bang-Bang game and found the purpose of the techniques applied. This research used translation techniques theory from Molina and Albir (2002). The data were popular mobile game Mobile Legend: Bang-Bang game. The source text in English and target text in Indonesian, then analyzed the technique that was applied in heroes background that was translated into Indonesia Language. This study method was qualitative study and this study was a primary research. The result of the analysis was ten techniques are applied in the data. They are reduction, transposition, compensation, modulation, amplification, borrowing-naturalization, particularization, establish equivalent, generalization, calque. The techniques applied have purposes for translation.
\end{abstract}

Keywords: Game translation, translation, translation process, translation technique

\section{INTRODUCTION}

An electronic game that represents the player with picture and sound is known as video game. In this era, video game can be finding easily in the console, computer, and hand phone. Even the video game player introduced themselves with the game only in short period and it was still continuing until now (Nielsen at al, 2016).

Mobile Legend: Bang-bang (MLBB) a Multiplayer Online Battle Area (MOBA) game which developed and launched by Moonton. Since 1990s technological development in multilingual communication is domain and there are new multimodal genres and text type such as media post, blog, web pages and emails (Munday, 2016). Even, through the time object and things that translator can translate increase for example: video game in much type of genres, and stories.

Translation becomes an important thing that people need. It is because the translation is needed to transfer the source language to target language. Munday (2016) states that changing the original text in the original verbal language into a written text in different verbal language is the process of translation. Translation technique is a way to transfer a meaning from SL into TL based on micro unit (Molina and Albir, 2002).
Translation techniques also allow people to describe the steps which are used by the translator.

Game that is already played in many country make the video game translation is started to be learns more. Video games also become one of products that affect the development of globalisation. It is because there are many popular games translated into several languages. Because of the game globalization, the enthusiast of game translation also increases. Video game translation is a blend of audio visual translation and software localization (Munday, 2016).

The purposes are to understand the techniques of translating a video game and to know which techniques applied in translating a video game titled Mobile Legend: Bang-bang. Then find the purposes of the techniques applied in target language.

This is useful for the next generation who want to learn about what techniques translation is applied on a game and translators who want to translate game is able to understand appropriate techniques to translate a game. 


\section{DISCUSSION}

The study was qualitative and quantitative study. This is also a primary research. The data was taken in MLBB gameheroes' background specially the heroes' background. The SL was taken from English and the translation was in Indonesian. The source text and the target text were aligned in a table and analyzed the technique. The result of the techniques applied is investigated deeper to find the purposes.

\section{Translation Techniques Applied}

The techniques are discussed from the highest applied to the lowest applied. There are ten techniques applied in this study, they are: reduction, transposition, compensation, modulation, amplification, borrowing-naturalization, particularization, established equivalent, generalization, and calque.

\section{Reduction Technique}

This technique suppresses the information in the SL. Translation techniques similar to omission where a word in the translation SL is deleted in the TL.

(1) SL: Her late father's mission

TL: Misiayahnya

This phrase is reduction technique because the word was not translated. Omitting a word in TL is reduction translation (Molina \&Albir, 2002). The translator does not translate the word "late" because in the second sentence of the profile had shown that her father was killed during an attack.

\section{Transposition Technique}

This technique functions to change the grammar category during the translation process. The most grammar category found are about the part of speech that is changed and the singularplural form.

(1) SL: During an attack

\section{TL: Selamadiserang}

The phrase applied transposition technique because the grammar is changed. The translator changed the part of speech from $(\mathrm{N})$ noun - "an attack" into (V) verb - diserang. The phrase "during an attack" is a noun phrase translated into selamadiserangas a verb phrase. It happened because the translator follows the TL structure.

\section{Compensation Techniques}

This technique introduces the information of the $S L$ in the different element that more natural in the TL. Compensation is used when the SL cannot be translated.

(1) SL: From the shadow

TL: Dari belakang

The phrase of ST "from the shadow" is compensation. It is compensation because "the shadows" in ST which is translated into belakanghas different meaning if it translated literally. The shadow is translated become daribelakang because the translator thinks that the shadows here mean is silently without Harley realize someone protect him. To make it more understandable the translator translates it into daribelakang.

\section{Modulation Technique}

This technique use different phrase in the SL and TL information. It is because modulation able to change the point of you in the text but still has same meaning.

(1) SL: The little Smilodon Leo

\section{TL: Leo sismilodonkecil}

The phrase of "the little Smilodon Leo" is modulation technique because the translator changes the point of view of the TL. This is modulation because "little" and "smilodon "is abound phrase which is little as modifier of the word Smilodon as Noun. However, "Leo" word is not bound into phrase the little Smilodon and the translator put the name of Leo in the beginning to follow the Indonesian structure and make the translation more natural.

\section{Amplification Technique}

This technique is adding more detail information of ST that is not really clear if it translate into TL without adding information. This technique is the opposition of reduction technique.
(1) SL: The secret base
TL: Tempatpersembunyianrahasia 
The noun phrase of "the secret base" is amplification techniques. Tempat is the translation of "base" and rahasia is the translation of "secret". However there is no translation of persembunyian. So, the translator uses amplification technique to add more information of persembunyian word. The translator uses amplification technique because the translator adds word persembunyianto make the TL more precise and the player in TL can understand that it is secret because the base is the place to hide out.

\section{Borrowing Technique}

This technique takes the SL directly when the translator translate it into TL. However, use borrowing-naturalization the translator able to translate the SL use the word that has naturalized in the TL.

(1) SL: The space portal

\section{TL: Portal ruang}

The noun phrase of "the space portal' is borrowing technique. It is because if the phrase is literally translated, the translation result should be pintugerbang. When player did not really pay attention with the whole sentence they may guess it as a simple gate. Based on the advance dictionary, the definition of gate and portal is actually different. The portal here is a gate that teleported people to the other place.

\section{Particularization Technique}

This technique gives more detail information of the SL through change the word that is common or not specific into specific one. The word that is used in the $T L$ have to give information that more precise and concrete.

(1) SL: Here

\section{TL: Lawn of Dawn}

The phrase is particularization because the word here is translated into a specific location that gives more detailed information in TL. The detail information can be seen in the word "here" which becomes Lawn of Dawn. It is argued that the translator wanted to show the specific location of the word "here" by using Lawn of Dawn instead. At that time, Lesley and Harley is staying in the Lawn of Dawn.

\section{Established Equivalent Technique}

This technique is used when the phrase in the SL already has common of equivalent in TL. Established equivalent mostly find the daily words that already familiar and known in the TL.

(1) SL: Under the full moon

TL: Disaatbulanpurnama

The phrase under the full moon is established equivalent technique because the phrase under the full moon if translated literally should be dibawahbulanpenuh. The translator translates the phrase "full moon" by using the phrase equivalent in TL. In Indonesia, when the moon is full, it is called purnama. Meanwhile, in the SL they do not have any specific name for that condition. Based on Molina and Albir, established equivalent is translating the SL using the familiar equivalent in TL (Molina \&Albir, 2002).

\section{Generalization Technique}

This technique translates the specific phrase in SL into general phrase in TL. This technique does not omit one of the word in the term or phrase but this technique changes the term.

(1) SL: The dark blessing

TL: pengaruh

The phrase of "the dark blessing" is generalization because the dark blessing actually has a different translation result where the translator generalizes the translation of "the dark blessing". In the Advance learner dictionary, blessing has a positive meaning for example protection from God. However, the blessing here is received from the evil. So, the translator generalized "the evil bless" become pengaruh. Generalization technique is generalize the precise information during translate the TL.

\section{Calque Technique}

Calques is a phrase borrowed from the SL phrase and translate it directly word per word. This technique often find in the formal terms.

(1) Code: H/N7/h

SL: Magical City

TL: Kota Ajaib 
The phrase Magical City is calque technique. It is calque because the translator translated lexically the phrase of Magical City. Vinay and Darbelnet's (1995) study explain calque mostly used for the specific terms and they are translated word per word. Magical city is a specific location in the game. Moreover the translator still translates it in TL. The translation of Magical City is found in Harley's profile. He is a hero that master in magic and he study in a Magical city. It is to show the player, Harley studies in the city that is full with miracle.

There are four kinds of phrases found in the 133 data. They are noun phrase, verb phrase, adverb phrase, and preposition phrase. From founded data there are ten techniques that were applied in this study. The highest that is applied is reduction with 35 data. Next, there are transposition technique with 18 data, compensation technique with 18 data and modulation technique with 18 data. Then, amplification technique with 15 data, borrowing naturalization technique with 10 data, particularization with eight data, established equivalent with five data. Eighth is generalization with three data. The lowest is calque technique with one data.

\section{Purposes of Technique Applied}

Based on the techniques applied, the following titles are the purposes:

\section{Avoiding Word Redundancy}

(1) SL: Under the moon's call. TL: -

The translator omitted the phrase of SL "under the moon's call" in the TL because it is already described on the previous sentence. In the previous sentence, there are sentences written that the evil power already contaminated Roger and during that time which means full moon he will change under the moon's call.

(2) SL: Who used his talent in magic to cause trouble for the Vance household TL: -
The translator did not translate SL of "who used his talent in magic to cause trouble for the Vance household" because Harley hero was introduced first before Lesley hero appeared. So, the reader already knew Harley is a mage hero who was excellent in magic. The previous sentence there is text written that Harley is a natural troublemaker and a sole heir of Vance family. It was the reason why the translator did not translate the SL of "to cause trouble for the Vance household".

(1) SL: To create

TL: Menciptakan

(2) SL: To invade

TL: Menyerang

The long sentence of those both $\mathrm{SL}$ is "they are also good at techniques that allow them to create a significant civilization and to invade the others". Meanwhile, the TL is merekajugabagusdalamteknik yang memungkinkanmerekamenciptakanperba daban yang significant and menyerang yang lain. This show that the translator did not the the word "to" in the SL because without translated the word, the TL of that actually should be untukmenciptakanatauuntukmenyerang already clear. Even, through omitting the word the sentence become simpler and still clear without losing any meaning.

\section{Naturalize the Translation to Ease the Reader}

(1) SL: During an attack

TL: Selamadiserang

The long SL of the example is "during an attack by a rival family" translated as "selamadiserangolehkeluargasaingan".

The result shows that the part of speech of the phrase was change. The SL of "during an attack" is Noun (N) and the TL of selamadiserangis Verb (V). If the translator translated the SL of "during an attack" literally it should be selamasuatupenyerangan. When the researcher read it with the long of SL it would

be selamasuatupenyeranganolehkeluargasai 
ngan". The sentence automatically heard awkward or did not natural in the TL structure. Meanwhile, when the part of speech was changed the sentence heard much more natural in TL.

(1) SL: After her escape

TL: Setelahmelarinkandiri

The second example shows that the SL of "after her escape" as Noun (N) translated became setelahmelarikandiri. It is show that the part of speech was changed. Meanwhile the literally the SL "after her escape" is setelahpelariannya. If the researcher combined the phrase with the next phrase the TL should be setelahpelariannyadarikematiandid not heard natural. So, the translator changes the grammatical element of SL to produce a natural sentence for $T L$ reader.

(1) SL: The boundaries.

TL: Perbatasan.

(2) SL: White tooth's steps.

TL: Jejak White tooth.

As we know that the plural form of in $T L$ is repetition word. It means those TL should be perbatasan-perbatasanand jejak-jejak White tooth. However, the translator did not translate the SL "the boundaries" and "White tooth's steps as plural in TL because the repetition word for plural form of target language does not a mandatory grammar.

(1)SL: from the shadows

TL: Dari belakang

As the explanation, the ST "from the shadow" is translated became daribelakangbecause the meaning of the shadow is Lesley was protecting her brother silently because the Vance family believed Lesley to protecting Harley and she think that her brother able to grew up and change by letting Harley through his experience. Meanwhile she still wanted to protect Harley because protect Harley is her responsibility from Vance family. So, to make the meaning of the shadows clearer the translator translates it into another element of information. Omission is used to omit redundancy and repetition of characteristic of the SL (Molina \&Albir, 2002, p. 504)

\section{Shorten or Simplify the Text}

(1) SL: Seiously

TL: Serius

(2) SL: Stories

TL: Cerita

If the adverb of SL "seriously" translated literally it should be denganseriusand the plural form of SL "stories" should be cerita-cerita. However, through changing the grammar element in $T L$, the phrase that actually should translated as two words in TL able to only become one sentence in TL without losing the SL meaning. Changing the grammatical category is used during the translation, because the language between SL and TL are incompatible (Molina \&Albir, 2002).

\section{Maintain the Logic}

(1) SL: Getting beaten to death

TL: Dipukulihinggasekarat

The literal translation of SL "getting beaten to death" in the TL should be dipukulihinggamati. The people who were getting beaten to death are Irithel and Leo. They were the heroes in MLBB game. In the end of the profile they are still alive. Even, Irithel able to understand human language and having combat skills and Leo grew up to a strong adult smilodon. It means they are did not death. So the translator translates it become sekaratwhich means they are only almost die.

(1) SL: came

TL: Turun

Based on the dictionary, came able to translate as datang, tiba, sampai, etc. However, the word "came" here translated as turun. It is because the previous phrase of came is the final tear came". In the TL, the condition of who is tearing is it out from the eyes and fall down to. To make the sentence more acceptable and logic the translator change 
the SL "came" as turun. Munday (2016) states that text is translated into another language to make the TL readers get the real meaning of the $S L$ in their own language.

Based on the purposes of technique applied the researcher find that every technique has its purposes why the technique applied. For the example, reduction technique has purposes to omit the repeating information and to avoid the word wastage. Transposition technique has purposes to change the grammatical aspect so the TL heard natural, translate singular and plural form should not translated in the same grammar, make the text shorter and simpler. Compensation technique has purposes to help the reader of TL more understand the real meaning of ST and make the TL heard more logic.

\section{CONCLUSION}

There are ten translation technique applied. They are reduction, transposition, compensation, modulation, amplification, borrowing-naturalization, particularization, established equivalent, generalization, calque. Based on the most applied technique in this study, the researcher found the purposes of why the translator often applied certain technique. The purposes are to omit information already explained in the previous sentence, to avoid wasting words, to change the grammatical aspect in order to make the TL sound natural, to translate the singular or plural form in the different grammar in $\mathrm{TL}$, to make the text shorter and simpler, to help the target reader easily understand the real meaning of SL, to make the TL or the translation sound natural and logic.

Translation technique is useful for the translation process for text in a game. The translation technique has very specific and detail process how to translate a text. The plot, skill, type, and character of game is related each other and it cannot just focus in one part of a game.

For translators who translate video games, they have to know and understand the character and plot of the game, because every plot, character, and skill are related one another. The translator should pay attention to terms that has possibility to be changed. There are also names that are able to be translated. 


\section{REFERENCES}

Molina, L., \&Albir, H. A. (2002). Translation Techniques Revisited: A Dynamic and Functionalist Approach. In Meta: Journal Des Traducteurs, 47(4), 498. doi: 10.7202/008033ar

Mobile Legend: Bang-Bang (n.d) Retrived April 16, 2016 from Mobile Legend Bang-Bang website, http://web.mobilelegends.com/

Munday, J. (2016). Introducing Translation Studies: Theories and Applications. London: Routledge

Egenfelt-Nielsen, S. E., Smith, J. H., \& Tosca, S. P. (2016). Understanding Video Games: The essential introduction. New York: Routledge/Taylor \& Francis Group.

R, J. I. (2018). Mobile Legends JadiGim Mobile Paling Hits Sepanjang 2017. Liputan6.com, p. 3. Jakarta. Retrieved from http://tekno.liputan6.com/

Vinay, J. P., \&Darbelnet, J. (1995). Comparative Stylistics of French and English. In A methodology for translation (11th ed.). Philade Iphia: John Benjamins 